\title{
Imitația și creația lexicală în limba română contemporană
}

\author{
Ana Ene* \\ Facultatea de Litere, Universitatea Transilvania din Brașov, Bd. Eroilor 29, 500036 Brașov, România
}

\section{Despre articol}

Istoric:

Primit 4 august 2019

Acceptat 1 septembrie 2019

Publicat 7 noiembrie 2019

Cuvinte-cheie:

semantică

sociolingvistică

stilistică

\begin{abstract}
Rezumat
Lucrarea investighează imitația și creația lexicală în limba română contemporană ca fiind importante procedee de dezvoltare a lexicului individual și colectiv, alături de diversele forme de împrumut propriu-zis și de procedeele interne lexico-gramaticale de îmbogățire a vocabularului.

Configurarea perimetrului investigației presupune 1) clarificarea celor două concepte, urmată de o încercare tipologică, dată fiind complexitatea fenomenului şi diversitatea ocurențelor sale, atît în limbajele de specialitate, în limbajul comun, cît și în cel familiar și argotic. Acestui prim obiectiv i se subordonează 2) identificarea și descrierea mecanismelor lexico-semantice implicate de imitaţia și creația lexicală. Cum imitația și creația lexicală sînt și o substanțială sursă de expresivitate, demersul nostru își propune și 3) studierea rolului aparte pe care îl dețin în dinamica argoului, în funcție de gradul de complicitate comunicațională determinat de astfel de elemente lexicale speciale.

Realizarea acestor obiective reclamă o metodologie general lingvistică, instrumentele aparținînd preponderent analizelor de tip semantic, lexical-paradigmatice. Dată fiind necesitatea luării în calcul a contextului, a parametrilor situației de enunțare și a cuantificării expresivității termenilor argotici, investigația de față va implica și instrumente ale analizei de tip pragmastilistic și sociolingvistic.
\end{abstract}

\section{Introducere. Clarificarea conceptelor}

Statutul aparte al limbii române, de unică reprezentantă a latinității în Europa de Est, i-a asigurat dea lungul timpului un loc important în literatura de specialitate. Singularitatea limbii române ca limbă romanică orientală este doar un aspect al interesului de care se bucură. Puternica individualitate a românei se vădește și în deschiderea spre împrumuturi și în marea sa forță creativă. Sintagma „limbă ospitalieră”, pusă în circulație de reputatul savant romanist suedez Alf Lombard (1969, p. 646), a făcut deja carieră, find nelipsită din studiile dedicate limbii române.

Imitația și creația lexicală sînt definite ca modalități ale dezvoltării lexicului individual și colectiv. Primul dintre aceste fenomene lexicale, imitația lexicalăa, este rezultatul preluării de către un vorbitor a unor cuvinte sau expresii auzite în diverse împrejurări, ca urmare a impresiei pe care i-au făcut-o sau a înțelegerii necesității includerii lor în bagajul lexical personal. Așadar, cel puțin într-o primă fază, resortul este de natură psihologică. Dacă receptarea s-a făcut adecvat, imitația inteligentă permite reproducerea acelor cuvinte în alte combinații decît cea auzită sau chiar crearea destul de rapidă de familii lexicale pornind de la baza rezultată prin imitație. Preluarea inadecvată conduce la imitația defectuoasă și are efecte cel puțin ilare (mai ales atunci cînd vorbitorul este pătruns de caracterul „elevat” al exprimării sale): Caragiale este un maestru în exploatarea artistică a greșelilor de limbă cu diverse conotații-antologica expresie „legea de murături" [sic!] este folosită de Conu Leonida ${ }^{1}$ pentru a-i explica pedant consoartei Efimița că legea în cauză (corect, [lege de] moratoriu ${ }^{2}$ — „lege care prevede amînarea plății datoriilor”) ar însemna că „nimini să nu mai aibă drept să-și plătească datoriile”. Sau, plasîndu-ne în cotidian, iată cum se exprimă o doamnă,

\footnotetext{
*Adresă de corespondență: enea@unitbv.ro.

${ }^{1}$ Personajul principal din comedia Conu Leonida față cu reacțiunea publicată în 1880.

${ }^{2}$ Greșeala lexico-semantică este generată, în mod evident, de omofonia dintre cei doi termeni, murături și moratoriu.
} 
dorind să-i comunice unei prietene că a fost nevoită să-și scurteze sejurul: „Dragă, deci fortuită de boala copilului, am fost obligată să mă întorc mai repede acasă”-dublă greșeală, căci fortuit (,întîmplător”), folosit de vorbitoare cu sensul „forțată, obligată”, este reluat prin verb. Aceste preluări defectuoase datorate neatenției, contextului minimal în care a fost receptat cuvîntul, precarităţii instrucției, sărăciei culturale—sînt generatoare de greșeli de limbă (etimologii populare, accidente semantice, incongruențe semantice, accidente fonetice etc.).

Cel de-al doilea fenomen lexical, creația lexicală (sau inovația lexicală) nu mai implică un model propriu-zis: „Tot ceea ce, în spusele unui vorbitor, se îndepărtează-ca mod lingvistic-de modelele existente în limba în care se stabilește conversația poate fi numit inovație” (Coșeriu, 1997, p. 70).

Creația lexicală are la bază un transfer și el motivat de factorul psihologic. Transferul se realizează în două feluri: transfer cu expresie materială și transfer färă expresie materială.

Transferul cu expresie materială constă în ataşarea unui sufix sau a unui prefix la un radical sau la o temă cu care nu se mai aflase pînă atunci în relație: de exemplu, sufixul neologic $-b i l<$ fr. $-b l e$, folosit inițial cu precădere în limbajul științific, s-a extins în limbajul administrativ și în cel literar, însă tot la cuvinte împrumutate. Ulterior, respectînd structura-bază (infinitiv + sufixul -bil), s-a transferat și la teme neîmprumutate și a generat formații analogice: apărabil, auzibil, locuibil etc. (Coteanu et al., 1985, p. 164). La fel ca în cazul anumitor imitații lexicale, creațiile cu acest tip de transfer la bază tind să-și dezvolte familii lexicale sau se pot reproduce ulterior în diverse combinații (întărite sau nu prin calc, deci o combinație de creație și imitaţie): albicios, alburiu, albişor, albior etc.; rasă albă, a semna în alb, albul ochiului, a fi alb ca varul, cu părul alb etc.

Transferul fără expresie materială afectează exclusiv conținutul semantic, fiind vorba de o resemantizare mai mult sau mai puțin complexă: se dă unui cuvînt un sens pe care nu l-a avut anterior și, mai mult decît atît, care nu are o legătură directă cu obiectul desemnat. Majoritatea acestor resemantizări sînt de fapt metafore, dar acel tip mai mult sau mai puțin criptic, care mai degrabă propune asemănări între elementele puse în relație decît evidențiază unele deja existente în realitate. Tipul așa-zis „clasic” de metaforă a fost definit deja foarte clar de Tudor Vianu:

O metaforă presupune alternarea în conștiință a două serii de reprezentări: 1) o serie a asemănărilor între realitatea desemnată în chip propriu prin cuvîntul respectiv și realitatea desemnată prin el în chip metaforic; 2) o serie a deosebirilor dintre cele două realități. Metafora este susținută psihologic de percepția unei unități a lucrurilor prin vălul deosebirilor dintre ele.

(Vianu, 1968, p. 307)

Prin urmare, transferurile de acest tip sînt mai mult sau mai puțin surprinzătoare: pe lîngă sensul lor de bază, cuvintele primesc (în limbajul comun) un sens adiacent care nu are (aproape) nicio legătură cu sensul denotativ. De exemplu, se spune gîscă unei femei considerate „proastă, neroadă, netoată, ușuratică”, iar cuvintul bou a ajuns să desemneze, la români, prostia masculină. De asemenea, nu de puține ori auzim în jurul nostru enunțuri de genul: Ești un porc! (pentru a desemna o persoană lipsită de scrupule / meschină / libidinoasă etc.), X se dă leu (pentru o persoană care mimează curajul / autoritatea) etc. Mecanismul metaforic implicat de aceste ultime exemple este ceva mai clar: se bazează fie pe o caracteristică evidentă a termenului comparator (curaj, pentru $X$ se dă leu), fie pe o trăsătură determinată cultural (murdăria, pentru Ești un porc!). Limbajul familiar-argotic furnizează nenumărate asemenea creații cu transfer semantic la bază, fără o legătură cel puțin aparentă cu sensul denotativ al lexemelor în cauză: pește pentru "proxenet”, curcan sau sticlete pentru „polițist”, termometru pentru „bastonul de cauciuc al polițiștilor” etc. Bineînțeles că în toate cazurile se poate găsi o oarecare motivare (gîsca nu se află în topul animalelor considerate inteligente, la fel boul; porcul nu este un animal dintre cele mai curate, leul este considerat „regele animalelor”; peștele este alunecos, curcanul are un aspect înfoiat, iar sticletele este o pasăre viu colorată, care atrage, așadar, atenția; termometrul are aspectul unei baghete). Așadar, această motivare fie nu este întemeiată strict științific, fie este o caracteristică secundară, mai mult sau mai puțin dependentă 
de arealul și tipul cultural. Oricare ar fi motivarea, aceasta apare însă, invariabil, ca rezultat al unui salt conotativ în creațiile lexicale respective.

Evident că astfel de creaţii lexicale, rezultate din transferuri fără expresie materială, există în majoritatea limbilor. Unele dintre aceste creații sînt adesea aduse în discuție în legătură cu deprecierea, una dintre cele două direcții facultative ale schimbărilor de sens:

Two other traditional categories in the analysis of meaning change are pejorization (Latin pejor 'worse') and ameliorization (Latin melior 'better'). These refer to change in word-evaluative force. In pejorization, a word takes on a derogatory meaning. This is frequently seen with words for animals, which can be used tot refer to people negatively or insultigly, as when someone is called a monkey, parasite, pig, sow, and so on.

[Alte două categorii tradiționale în analiza schimbării de sens sînt peiorativizarea [deprecierea sau degradarea-nota mea] (din lat. pejor „mai rău”) și ameliorarea [înnobilarea-nota mea] (din. lat. melior „mai bine”). Acestea se referă la schimbarea produsă în forța de evaluare a cuvîntului. În peiorativizare, un cuvînt capătă un sens derogativ [care reprezintă o abatere execepțională de la sensul de bază - nota mea]. Acest lucru se întîmplă adesea la cuvinte desemnînd animale, care pot fi utilizate pentru a se referi la oameni în mod negativ sau insultător, ca atunci cînd cineva este numit maimuță, parazit, porc, scroafă și așa mai departe.]

(Riemer, 2010, p. 374-375)

În limbajul poetic, astfel de creaţii (care pot fi şi transferuri cu expresie materială) sînt dominante, ele îmbracă diverse forme de realizare și au la bază mecanisme și asocieri uneori foarte greu de depistat. Alteori, transferul material poate fi mimat: un sufix lexical/gramatical poate fi ataşat la o bază inexistentă anterior. Iată, de exemplu, termenul trimbulind (folosit atît ca adjectiv, cît și ca substantiv și avînd și plural: trimbulinzi), creație lexicală a poetului Nichita Stănescu ${ }^{3}$. Sufixul atașat aici la o bază inventată este unul gramatical, sufix de gerunziu, iar cuvîntul rezultat este convertit morfologic la adjectiv sau la substantiv.

Evident că și în cazul creației lexicale se poate vorbi de creații lexicale inteligente sau doar de „creații de moment" $(1,4,5)$, justificate, de regulă de un context/registru stilistic marcat ironic (Guțu-Romalo, 2000, p. 175), dar și de creații mai puțin inspirate (2, 3):

(1) amicalitate: „Starea de amicalitate produce numai propoziții în care evlavia se îmbină cu adorația”, în „Săptămîna” 1971, nr. 10, p. 7/1 (Guțu-Romalo, 2000, p. 175-176); cuvînt format de la amical cu sufixul -itate; derivatul dublează substantivul abstract, bine încetățenit în română, amiciție;

(2) pierzant: „Marele pierzant ... este, însă, guvernul de centru-dreapta”, în „Lumea”, 1980, nr. 50, p. 6, col. 2 (Avram, 1987, p. 247); creaţie lexicală cu baza a pierde (plus sufixul -ant), utilizată în detrimentul neologicului perdant (fr.), probabil, sugestia prin evocare a substantivului pierzanie fiind considerată mai potrivită cu contextul și situația de enunțare;

(3) vizuiență: „uriașa audiență sau vizuiență a filmului”, în „Luceafărul”, 1980, nr. 17 (943), p. 4, col. 3 (Avram, 1987, p. 247); aici se vede clar analogia forțată cu audiență, ca și cînd ar fi format cu sufixul -ență, deși acesta este formație neologică (provine din fr. audience); oricum, substantivul românesc audiență (avînd sensul iniţial de „întrevedere acordată unui solicitant de către o persoană cu funcție de răspundere") și-a adăugat prin calc semantic sensul lui audience din engleză relativ recent;

(4) cîrtiţărit: „industria cîrtiţăritului”, în „Scînteia”, 1982, nr. 12405, p. 6, col. 6 (Avram, 1987, p. 241); cuvîntul se referă la „industria” adăposturilor subterane și este uşor de decodat în context (cîrtiţă plus sufixul -(ăr)it), cu condiția stăpînirii limbajului comun (cazul vorbitorilor nativi);

\footnotetext{
${ }^{3}$ Termenul apare în mai multe poeme: de exemplu, în poemul Cîntec în doi („Noi nu vrem să fim geniali / Noi vrem să fim trimbulinzi”) din volumul Necuvintele publicat în 1969. Sintetizînd, termenul a fost interpretat ca „nonconformist”, „dornic de cunoaștere, deschis la experiențe noi”.
} 
(5) profitozaur: Profitozaurii - titlu de articol, în „Informația Bucureștiului”, 1983, nr. 9224, p. 4, col. 13 (Avram, 1987, p. 241); este o creație lexicală de tip cuvînt-valiză, în care se pot recunoaște lexemele profitor și dinozaur (cărora li se aplică operația suprimării urmate de cea a adjoncției), și se referă la miliardarii cu cele mai mari profituri.

Presa uzează, dar și abuzează uneori, de formații glumețe ad-hoc, creații ocazionale precum cele prezentate. Spre deosebire de imitațiile lexicale, fixarea în limbă a creațiilor lexicale (și, ca urmare, înregistrarea lor în dicționare) este mult mai puțin probabilă, dată fiind aproape invariabila expresivitate implicată, contextele în care apar fiind de tip virtuemic (implicind cel mai adesea de conotaţii ocazionale, ca simple posibilități, și nu conotații consacrate în limbă, care caracterizează semnul în ansamblul lui, ca în cazul polisemiilor).

\section{Imitaţia și creația lexicală - o încercare tipologică}

Nu ne propunem în cele ce urmează să oferim liste generoase de exemple. Acestea există deja, prezentate din varii perspective și însoțite de comentarii subtile, în studii consacrate, semnate de autori precum: Dimitrescu (1994, 1997), Hristea (1984), Bidu-Vrănceanu (1997), Avram (1997), Guţu-Romalo (2000, 2005), Zafiu (2001, 2010), Gruiță (2006), Stoichițoiu-Ichim (2007).

Ne propunem doar o schiță tipologică, dat fiind că aceste fenomene apar descrise, exemplificate din perspectiva dinamicii lexicului limbii române, laolaltă cu altele, în studiile menţionate.

\subsection{Imitația lexicală}

În cele ce urmează, voi prezenta imitația lexicală aşa cum apare în limba română contemporană, dar și modul în care este descrisă în literatura de specialitate recentă.

\subsubsection{Imitația lexicală rezultată din împrumuturile propriu-zise}

Formele de imitație lexicală rezultată din împrumuturile propriu-zise sînt foarte bine reprezentate în limba română contemporană: binom < fr. binôme, paralelipiped < fr. parallélipipéde, congruență < fr. congruence, atom < fr. atom, nucleu < fr. nucléus, eprubetă < fr. éprouvette, clorofila $<$ fr. chlorophylle, ferigă $<$ lat. filix, -icis, fortuit $<$ fr. fortuit, salutar $<$ fr. salutaire, summum < lat. summum, vindicativ $<$ fr. vindicatif, a implementa $<$ eng. to implement, a derula $<$ fr. dérouler, vizavi $<$ fr. vis-à-vis etc.

În ce privește fixarea formelor de acest tip în limbă, dăm cuvîntul unei autoare care a studiat și acest fenomen:

Rolul benefic sau dăunător al învățării prin imitare depinde de calitatea modelului, iar exercitarea influenței lui asupra limbii utilizate la un moment dat prin impunerea unor anumite modalități de exprimare depinde de frecvența cu care modelul se regăsește în comunicarea socială sau/și de autoritatea de care se bucură categoria de locutori care îl reprezintă.

(Guțu-Romalo, 2005, p. 249).

\subsubsection{Imitația lexicală rezultată prin calchiere}

În tipologia calcului, criteriul lingvistic este cel care contează: „Întrucît indică exact ramura lingvistică în care se produce o imitație, criteriul lingvistic poate fi considerat cel mai important în clasificarea calcului” (Stanciu-Istrate, 2006, p. 309).

Criteriile structurale, anume al traducerii elementelor care intră în alcătuirea modelului (după care avem calcuri parțiale sau integrale) și acela al gradului de fidelitate a copiei față de model (după care avem calcuri aproximative, imperfecte și perfecte) sînt considerate subcriterii, adică subordonate celui lingvistic.

Într-adevăr, acestea sînt „criterii [...] secundare întrucît nu aduc în discuție noi tipuri de calc, ci arată cum se realizează cele deja identificate pe baza criteriului lingvistic” și, mai mult decît atît, „un calc lexical de structură morfematică poate fi, în același timp, perfect și parțial (ex.: prevedea), perfect și total (ex.: 
simțămînt), imperfect și total (ex.: anotimp), aproximativ și total (ex.: însărcina)" (Stanciu-Istrate, 2006, p. 309-310).

În clasificarea calcurilor, se mai ține cont de subcriteriile: sociocultural (calcuri populare și savante) și al originii modelului (calcuri cu model unic, calcuri multiple și calcuri internaționale).

Așadar, se pot distinge șapte tipuri fundamentale de imitație prin calchiere:

- calcul lexical: a) de structură morfematică - abstrage < fr. abstraire, demers < fr. démarche; b) de structură semantică - aer „mină, alură, aparență” < fr. air, pătură „categorie socială” < fr. couche;

- calcul gramatical: de conivență cu ,în complicitate cu”, ,de acord cu” < fr. de connivence avec;

- calcul frazeologic: arte frumoase < it. belle arti, cf. și fr. beaux-arts;

- calcul lexico-frazeologic: caz de conștiință < fr. cas de conscience; curtea de apel < fr. la cour d'appel;

- calcul lexico-gramatical: ținută „atitudine, poziție” < fr. tenue;

- calcul frazeologico-gramatical: ape subterane < fr. eaux souterraines;

- calcul lexico-frazeologico-gramatical: însărcinat cu afaceri < fr. chargé d'affaires; limbă de lemn < fr. langage de bois.

Calcul lexical de structură semantică, numit și împrumut semantic în literatura de specialitate, se circumscrie fenomenului mai larg al polisemiei, sensurile noi nefiind însă înregistrate toate în dicționare. Unele dintre acestea tind să se fixeze în limbă, altele sînt simțite ca barbarisme, dublete neologice forțate, chiar inutile. Ele intră în special prin mass-media: „limba română este, într-o măsură îngrijorătoare, incorect și neglijent vorbită la radio și televiziune” (Guțu-Romalo, 2005, p. 250), însă o „contribuţie” o au indiscutabil și mediile de comunicare în spaţii virtuale (Facebook, chat etc.). Reglajele fine ale sistemului lingvistic, determinate mai ales de factorul cultural, vor decide în timp adoptarea sau respingerea acestor noi sensuri: „[...] dacă este adevărat că individul vorbitor creează limba, tot atît de adevărat este că societatea este aceea care o perfecționează. Ea alege sau respinge modificările ce se nasc în limbă, după cum ele se potrivesc sau nu cu sistemul creat de colectivitate" (Capidan, 1943, p. 8-9).

La formele semnalate deja în literatura de specialitate recentă (de exemplu, Stoichițoiu-Ichim, 2007, p. 58-63), se adaugă alte cîteva împrumuturi semantice apărute în limbajul comun în ultima vreme. Iată cîteva dintre cele mai frecvent folosite în diverse situații și registre de comunicare:

(6) ataşament: după engl. attachment, în mesajele tip e-mail (sau despre), „la mesaj sînt două ataşamente”, în loc de „fișier anexat”, sens care generează omonimie cu forma existentă în română, ataşament ( $<\mathrm{fr}$. attachement), însemnînd „afecțiune puternică sau durabilă pentru cineva/ceva”;

(7) determinat: după engl. determined, mai ales în limbajul fotbaliștilor/comentatorilor sportivi, „Echipa a avut un joc determinat", în loc de hotărît, precis, coerent; dublet inutil și generator de confuzii, sensul lui determinat în română (< fr. déterminé) fiind „definit, precizat, stabilit”;

(8) (a se) focusa (pe): după engl. to focus on, în „a se focusa pe absorbția de fonduri europene”, în loc de a se concentra pe; în acest caz, calc lexico-gramatical—în română verbul nu există ca atare, există doar focusare (< germ. fokussieren), dar folosit cu sens tehnic („concentrarea într-un focar a razelor de unde sau de particule în mișcare”), în sinonimie cu focalizare;

(9) graduare: după engl. graduation, în „ceremonie de graduare”, în loc de absolvire; dublet inutil și generator de confuzii, vezi paronimia cu gradare „a mări/micșora treptat; a eșalona” < a grada (fr. graduer) plus sufixul -re;

(10) nutrient: după engl. nutrient, în, de exemplu, „lapte bogat în nutrienți”, în loc de „[substanțe] nutritive, hrănitoare"; este, mai degrabă, împrumut propriu-zis, în rom. există doar adj. nutritiv (< fr. nutritif) și subst. nutriment ( $<$ fr. nutriment);

(11) patetic: după engl. pathetic, în „a eșua patetic”, în loc de lamentabil, jalnic; dublet resimțit ca inutil și în contradictoriu cu sensul din română (< fr. pathétique) „plin de patos”;

(12) audiență: după engl. audience, într-un enunț ca „Audiența a aplaudat minute în șir”, în loc de public, asistență dublet inutil și ambiguizator, în română substantivul audiență (< fr. audience) avînd sensul „întrevedere acordată cuiva de către o persoană care deține o funcție de răspundere” sau „a trezi 
interesul cuiva/a avea influență asupra cuiva” pentru expresia a avea audiență la;

(13) expertiză: după engl. expertise, în exemple ca "persoană cu expertiză în domeniu”, „Expertiza lui în domeniu este impresionantă", utilizate cu sensul de experiență, competență deosebită; în română, expertiză (< fr. expertise) înseamnă „cercetare întreprinsă de un expert cu privire la o situație, la o problemă etc.; raport al unui expert";

(14) vocal: după sensul „,sonorous” al adjectivului engl. vocal, în sintagme ca "politician vocal”, în loc de zgomotos, activ (care dorește să se remarce); în română, vocal (< fr. vocal) are sensul „referitor la voce; executat cu vocea" - prin urmare, termenul deja existent în limba română are sensul de bază, cel al utilizării efective a vocii.

Toate formele de mai sus generează mai degrabă omonimie decît polisemie, dacă ținem cont că sensul nou este calchiat după un alt etimon decît cel al sensului/sensurilor deja existent(e) în română.

\subsection{Creația lexicală}

Deschiderea limbii române către împrumut (propriu-zis sau de tip calc) îndreptățește sintagma „limbă ospitalieră” a lui Lombard (1969, p. 646). Această ospitalitate, expresie a evoluției lexicului „în direcția modernizării și internaționalizării” (Stoichițoiu-Ichim, 2007, p. 7), așază limba română în postura unei limbi mai mult sau mai puțin comprehensibile pentru străini în multe domenii de comunicare (tehnică, știință, informatică, economie, presă, publicitate, sport, artă și industria spectacolului etc.). Puternica influență a limbilor romanice, exercitată încă din prima fază a modernizării lexicului limbii române, și împrumuturile tîrzii din latină, impuse de curentul relatinizării, pe de o parte, și la fel de puternica influență anglo-americană, pe de altă parte, fac româna literară inteligibilă pentru străinii vorbitori de limbi romanice sau care cunosc una sau mai multe astfel de limbi şi/sau latina, dar și pentru vorbitorii nativi sau non-nativi ai limbii engleze. La această comprehensibilitate contribuie și multitudinea de cuvinte din româna modernă care intră în categoria termenilor internaţionali (de origine greco-latină), deci comuni unui mare număr de limbi.

Complementară acestei ospitalități este extraordinara inventivitate lexicală a limbii române, ceea ce îi asigură identitatea, alături de conservarea celorlalte elemente specifice. „Între limbă și cultură există o reciprocitate: limba ajută cultura și cultura ajută limba. În viața unei limbi se deosibesc de obicei două perioade de desvoltare: una de acumulare, alta de prelucrare a materialului lingvistic cu ajutorul culturii." - spunea Theodor Capidan în (1943, p. 1-2).

Dacă dincolo de orientarea organicistă a acestei afirmații putem vedea cele două perioade ca iterative (sau chiar concomitente uneori) în dinamica limbilor, atunci fenomenul imitaţiei caracterizează mai degrabă fazele de acumulare ale unei limbi, iar creația lexicală poate fi asimilată fazelor de prelucrare prin intermediul culturii.

Transferul poate fi considerat fără probleme un criteriu justificat de clasificare a creaţiilor lexicale, procedeele prin care se ajunge la astfel de creații fiind doar generatoare de subcategorii ale celor două principale. Aceste subcategorii au fost deja descrise și excelent comentate de Stoichițoiu-Ichim (2007, p. 7-15), dar tratate din perspectiva dinamicii recente a limbii române prin mijloace interne de îmbogățire a vocabularului. Așadar, în clasificarea de mai jos, am ales drept subcriteriu registrul stilistic. Au rezultat astfel două mari categorii, fiecare cu subcategoriile sale: creații lexicale prin transfer cu expresie materială și creații lexicale prin transfer färă expresie materială.

\subsubsection{Creații lexicale prin transfer cu expresie materială}

Majoritatea exemplelor sînt preluate din volumul autoarei citate, la care am adăugat formele bunsimțisme, big-mama, Berceni Style, departe, încălzitoare, mîrîitor, Intunericitul.

Iată, așadar, cele două tipuri aparținînd creațiilor lexicale obțtinute prin transfer cu expresie materială: 
a) creații lexicale „necesare" ${ }^{4}$ : i) prin derivare - antologabil < a antologa + sufixul -bil, cartelizare < a carteliza + sufixul -re, superaccesorizat < super + accesorizat, accept, antologa etc.; ii) prin compunere actor-vedetă, oraș-stațiune, microinterviu, teledivertisment, Oltchim <Olt +- chim-, CEDO; iii) prin trunchiere - afro, homo; iv) prin conversiune - audiovizual, anticonceptional - folosite ca substantive;

b) creații lexicale, "de lux" : i) prin derivare - aplaudac < a aplauda + sufixul - ac, răspîndac < a răspîndi + sufixul -ac, spionită < spion + sufixul -ită, cuponiad $\breve{a}<$ cupon + sufixul -(i)adă, fesenizare (de la $\left.F S N^{6}+-i z a+-r e\right)$, becalizare (Becali $\left.i^{7}+-i z a+-r e\right)$, bunsimțisme ${ }^{8}$ (din substantivul compus bun-simț $+-i s m)$; ii) prin compunere - big-mama ${ }^{9}$, Berceni Style ${ }^{10}$; iii) prin trunchiere - secu < securist, prof < profesor, bac < bacalaureat; iv) prin conversiune - departe ${ }^{11}$, incălzitoare ${ }^{12}$, mîrîitor ${ }^{13}$, Intunericitul $^{14}$ (semnatarul rubricii „Bula demnitarului”).

În subcategoria creații „de lux” prin conversiune, trebuie să menţionăm și următoarea situație, existentă şi în alte limbi, privitoare la părți de vorbire care, prin sufixare (lexicală sau gramaticală), își schimbă statutul morfologic. Riemer (2010, p. 302) semnalează și el asemenea situații: Don't baby me; just Google it sau Don't "madame" me, young man! I don't like it... Autorul citat precizează de asemenea că aceste posibilități nu se limitează la substantive și verbe ${ }^{15}$. Astfel de formaţii se regăsesc și în limbajul colocvial în română, în enunțuri de tipul Nu mă mai „dumnevostri” / „domni” atîta!

\subsubsection{Creații lexicale prin transfer färă expresie materială}

Aceste creații lexicale sînt rezultatul unei modificări semantice în diverse grade, operate în interiorul sememului, prin extensie sau restrîngere de sens, cu sau fără înnobilare/depreciere de sens, implicînd într-o măsură mai mare sau mai mică acțiunea unui trop.

Modificarea prin extensie/restrîngere se produce fără ca vreun sens al etimonului să fie implicat, din rațiuni denominative, aceasta fiind așa-numita neologie denominativă ${ }^{16}$. Cînd sînt implicați tropii, vorbim despre neologie stilistică.

Există însă și o categorie de creații lexicale care presupun o resemantizare profundă, cu un grad de expresivitate mai mare, creațiile lexicale de tip cuvînt-valiză. Pe acestea din urmă nu le putem integra în neologia stilistică, deoarece se pleacă de la două sau mai multe baze, una dintre ele predominînd ca sens.

Toate aceste tipuri ${ }^{17}$ au fost descrise și bogat exemplificate, din alte perspective, de Stoichițoiu-Ichim (2007, p. 13-14, 55-79). În clasificarea de mai jos ne folosim și noi de cîteva dintre aceste exemple, dar vom completa și cu exemple proprii pentru aceste categorii.

În fine, tot creații lexicale sînt și formațiunile/structurile aluzive, uneori încărcate de intertextualitate, evocînd mai discret sau mai puțin discret diverse lucruri, situații, personaje publice, literare etc. Apar,

\footnotetext{
${ }^{4}$ Prin extensie de la distincția derivate „necesare”/ „de lux”, propusă de Sextil Pușcariu, în Limba română, I. Privire generală, 1976 (apud Stoichițoiu-Ichim, 2007, p. 8).

5 Ibidem.

${ }^{6}$ Frontul Salvării Naționale, formațiune politică (constituită după Revoluția din Decembrie).

${ }^{7}$ (George) Becali, figură publică controversată.

${ }^{8}$ Creație lexicală obținută prin compunere și derivare, aparținînd lui Andrei Pleșu (art. Capitalistul român, în „Dilema Veche", nr. 201, dec. / 2007).

'În limbaj argotic-familiar, cu sensul „grăsană”, [online].

${ }^{10}$ Numele unui grup de suporteri ai echipei de fotbal Rapid din cartierul Berceni din București, [online].

${ }^{11}$ În limbaj argotic-familiar, ca adjectiv invariabil (din adverb), cu sensul „drogat”, [online].

${ }^{12}$ În limbaj argotic, ca substantiv (din adjectiv), cu sensul „amantă”, în George Volceanov, Dicționar de argou al limbii române (2007).

${ }^{13}$ În limbaj argotic, ca substantiv (din adjectiv), cu sensul „delator (fost/actual infractor)”, [online].

${ }^{14}$ Substantiv din participiul pop. întunericit (prin articulare hotărîtă), pseudonimul semnatarului rubricii Bula demnitarului din publicația satirică „Academia Cațavencu”.

${ }^{15}$ Vezi de asemenea: „These possibilities are not limited to nouns and verbs” (Riemer, 2010, p. 302).

${ }^{16}$ Louis Guilbert, La créativité lexicale, 1975 (apud Stoichițoiu-Ichim, 2007, p. 55).

${ }^{17}$ Toate cazurile de calc semantic semnalate de autoarea citată (Stoichițoiu-Ichim, 2007, p. 58-63) le considerăm imitații prin calchiere, dat fiind că, în aceste cazuri se dezvoltă o polisemie facilitată de acelaşi etimon care a mai furnizat sensuri în română.
} 
evident, cu frecvență mai mare în literatură sau în presa (declarată sau nu) pamfletară. Pe acestea le vom numi creații lexicale evocative (exemplele sînt din „Academia Cațavencu” ${ }^{18}$, de aici înainte AC).

Așadar, se pot distinge următoarele tipuri de creații lexicale prin transfer fără expresie materială:

a) creații lexicale prin neologie denominativă: actor (politic), algoritm (politic); asanare (morală), paliere (ale puterii), segment (de public), (investitor) strategic, inginerie (financiară) etc.;

b) creații lexicale prin neologie stilistică: seism (social), mamut (industrial), dinozaur (politic), barometru (politic), bumerang (electoral), firmă-căpuşă $\breve{1}^{19}$, cancerul (corupției), mineriad $\breve{a}$ (financiară), burtă (textuală), capră (de femeie) etc.;

c) creații lexicale de tip cuvînt-valiză: ofțţăran (ofțter + țăran) sau intelectocan (intelectual + mitocan), (a) shoppingoni (shopping + (a) goni; pentru a descrie febra cumpărăturilor, în AC, nr. 1, 6.01.12.01.2004, p. 5), publireportaj (publicitate [ascunsă] + reportaj, în AC, nr. 5, 3.02.-9.02.2004, p. 5; autorul explică ironic sensul: „Publireportajul este un gen jurnalistic care, în schimbul unei anumite sume, face ce vrea clientul"); singur ciuciulete (expresie-valiză din poemul Expresii improprii al Ninei Cassian: singur cuc + ud ciuciulete ${ }^{20}$ ) etc.;

d) creații lexicale evocative: Platon și Aristotel baronizîndu-se niţel / separatiști de tip Bruxelles (pseudonim folosit în AC, seria a doua, care rimează întotdeauna cu Aristotel, fluctuează în funcție de cele descrise în articolele semnate), Grigore după Ureche (pseudonim în AC), Ethos, Porthos şi Aramis (semnatarii rubricii Mici fragmente de neant, în AC), Bursucul gastric (semnatarul rubricii Localul bălan, în AC), Cronică a lu'Ștefan a Petrei (semnatarul rubricii Săptămîna românilor, în AC) etc.

\section{Creația lexicală și complicitatea comunicațională}

Din perspectivă sociolingvistică, atît imitația, cît și creația lexicală pot fi înțelese ca alegeri lexicale (vocabulary choices), în termenii lui Holmes (1997, p. 7), alegeri determinate de diverși factori:

Not all factors are relevant in any particular context but they can be grouped in ways which are helpful. In any situation linguistic choices will generally reflect the influence of one or more of the following components

1. The participants: $w h o$ is speaking and who are they speaking to?

2. The setting or social context of the interaction: where are they speaking?

3. The topic: what is being talked about?

4. The function: why are they speaking?

[Nu toți factorii sînt relevanți în orice context particular, dar pot fi grupați în moduri utile. În orice situație, alegerile lingvistice vor reflecta, în general, influența uneia sau a mai multor componente dintre următoarele:

1. Participanții: cine vorbește și

cu cine vorbesc ei?

2. Cadrul sau contextul social al interacțiunii: unde vorbesc ei?

3. Subiectul: despre ce se vorbește?

4. Funcția: de ce [în ce scop] vorbesc?]

(Holmes, 1997, p. 12).

Este de așteptat ca, în funcție de toți acești factori, să se instituie o anume solidaritate sau, dimpotrivă, o anume distanță în comunicare. Într-o altă lucrare (Ene, 2012b), am numit această solidaritate complicitate

\footnotetext{
${ }^{18}$ Publicație satirică fondată în 1991.

${ }^{19}$ Mai nou, și căpușarea (economiei).

${ }^{20}$ Vezi analiza pe larg a expresiilor-valiză în Ene (2012a).
} 
comunicațională, cu referire la argou. Am încercat să ilustrez acolo balansarea ponderii dinspre codificare spre expresivitate în argou, fără pierderea ideii de apartenență la grup/comunitate, pe de o parte, și păstrarea funcției criptice (dacă apare nevoia ca membrii grupului să nu fie înțeleși de outsideri) tot prin expresivitate, pe de altă parte.

În aceeaşi lucrare (Ene, 2012b), am mai arătat că unele dintre elementele argotice intră/pot intra în limbajul comun tocmai datorită atracției exercitate de gradul de fantezie și umor implicat de acestea. Miam pus atunci problema dacă expresivitatea, care joacă un rol important în deschiderea argoului, ca limbaj secret, către tipuri de argou mai permisive sau chiar către ale tipuri de limbaj (popular, familiar etc.), nu cumva joacă și un rol de inchidere, către un argou în sensul tare al termenului. Analiza efectuată pe trei microserii (pentru închisoare, amantă și informator) ne-a ajutat să conturăm ipoteza că se pot distinge o complicitate comunicațională argotică intrinsecă (CCAI) și o complicitate comunicațională argotică extrinsecă (CCAE).

Această complicitate comunicațională argotică este invers proporțională cu expresivitatea implicată de resemantizarea termenilor preluați din limbajul comun: CCAI presupune o expresivitate (în special prin intermediul metaforei) care vizează nucleul semic, al semelor de substanță, iar CCAE presupune o expresivitate (mai ales prin tropi din clasa metonimică) care vizează periferia semică, al semelor aferente sau contextuale.

Conform încercării noastre tipologice, conceptul complicității comunicaționale nu se poate extinde la imitație, dar se poate pune în relație cu unele tipuri de creație lexicală-mai exact, cu creațiile lexicale „de lux" (din prima categorie) și, respectiv, cu creațiile lexicale de tip cuvînt-valiză și cu creațiile lexicale evocative (din categoria a doua). Toate aceste tipuri de creație lexicală presupun o expresivitate ce nu s-ar putea realiza în orice condiții, pentru orice receptor, au un caracter mai mult sau mai puțin elitist, aceasta însemnînd că implică o anumită inițiere.

\section{Concluzii}

Imitația lexicală și creația lexicală sînt cazuri de creativitate lingvistică foarte bine reprezentate în limba română—ele asigură dezvoltarea lexicului individual și pe a celui colectiv.

Imitaţia lexicală caracterizează, în principal, fazele de acumulare ale unei limbi, iar creaţia lexicală poate fi asimilată fazelor de prelucrare prin intermediul culturii, fanteziei, imaginației fiecăruia dintre noi.

Creația lexicală, prin formele ei care se fixează în limbă sau prin puterea de circulație pe care o dobîndesc ca elemente creative deosebite în literatură, asigură, alături de alți factori, identitatea limbii române și este expresia inventivității vorbitorilor ei. Această afirmație se bazează pe un fapt: fenomenele prezentate aici implică adesea—în formele lor inspirate—-metafora, o expresie a unei mișcări foarte rapide a minții, așa cum Tudor Vianu a descris cîndva esența acestui mecanism (Vianu, 1968, p. 312).

Expresivitatea implicată de unele tipuri de creație lexicală presupune o complicitate comunicațională fără de care acestea nu ar fi posibile. Rămîne ca timpul și dezvoltarea noastră culturală să reducă din caracterul elitist, dar reușit al unora dintre ele, spre delectarea cît mai multor minți.

\section{Bibliografie}

Avram, M. (1987). Probleme ale exprimării corecte, EARSR, București. Avram, M. (1997). Anglicismele în limba română actuală, Editura Academiei Române, București.

Bidu-Vrănceanu, A. (1997). Dinamica sensurilor în româna actuală, în LL, 3-4, p. 39-44.

Capidan, Th. (1943). Limbă și cultură, Fundația Regală pentru Literatură și Artă, București.

Coteanu, I., Forăscu, N. \& Bidu-Vrînceanu, A. (1985). Limba română contemporană. Vocabularul, EDP, București.

Coșeriu, E. (1997). Sincronie, diacronie și istorie, Editura Enciclopedică, București.

Dimitrescu, F. (1994). Dinamica lexicului românesc - ieri și azi, Editura Logos, București.

Dimitrescu, F. (1997). Dicționar de cuvinte recente, Editura Logos, București.

Ene, A. (2012a). Peritextual Dialogue in The Dynamics of Poetry Translatability, în Ubaldina-Lorda, C. \& Zabalbescoa, P. (eds), Spaces of Polyphony, John Benjamins Publishing Company, Amsterdam, Crossref. 
Ene, A. (2012b). Aspecte ale resemantizării în argou, în Buja, E. \& Măda, S. (eds), Structure, Use, and Meaning. Linguistic studies, Casa Cărții de Știință, Cluj-Napoca.

Gruiță, G. (2006). Moda lingvistică 2007, Editura Paralela 45, Pitești.

Guțu-Romalo, V. (2000). Corectitudine și greșeală, Editura Humanitas Educațional, București.

Guțu-Romalo, V. (2005). Aspecte ale evoluției limbii române, Editura Humanitas Educațional, București.

Holmes, J. (1997). An Introduction to Sociolinguistics, Longman, London \& New York.

Hristea, Th. (1984). Sinteze de limba română, ed. a III-a, revăzută și din nou îmbogățită, Editura Albatros, București.

Lombard, A. (1969). Le vocabulaire d'emprunt. Questions de principe, în „Actes du X Congrès International des Linguistes”, București.

Riemer, N. (2010). Introducing Semantics, Cambridge University Press, Cambridge, Crossref.

Stanciu-Istrate, M. (2006). Calcul lingvistic în limba română. (Cu specială referire la scrieri beletristice din secolul al XIX-lea), Editura Academiei, București.

Stoichițoiu-Ichim, A. (2007). Vocabularul limbii române actuale. Dinamică, influențe, creativitate, Editura BIC ALL, București. Vianu, T. (1968). Problemele metaforei, în Studii de stilistică, EDP, București.

Volceanov, G. (2007). Dicționar de argou al limbii române, Editura Niculescu, București.

Zafiu, R. (2001). Diversitate stilistică în româna actuală, Editura Universității din București, București.

Zafiu, R. (2010). 101 cuvinte argotice, Editura Humanitas, București. 